\title{
Synthetic Study towards (-)-Allosedridine
}

\section{Feifei Huang ${ }^{1}$, Zhibin Zhang ${ }^{1}$, Shuangjie Lin $^{1}$, Shuangping Huang ${ }^{1, \text { a }}$, Xiaoji Wang ${ }^{1, b}$}

${ }^{1}$ School of Pharmacy, Jiangxi Science and Technology Normal University, Jiangxi 330013, China a185544590@qq.com, b13767101659@163.com

Keywords: Piperidine; alkaloid; (-)-allosedridine; synthesis

Abstract. The synthesis of (R)-3-((4-methoxybenzyl)oxy)butanal, which is an intermediate of (-)-Allosedridine, a 2-substituted piperidine alkaloid, was described, The route started from (R)-methyl 3-hydroxybutanoate via a PMB protection, a $\mathrm{LiAlH}_{4}$ reduction and a Swern oxidation.

\section{Introduction}

2-Substituted piperidine alkaloids (Figure 1) are a series of nature products with novel biological activities, which were widely distributed in nature ${ }^{[1]}$. As these alkaloids are obtained in only trace amounts from natural sources, there is a great need to develop diverse methods for their syntheses. Piperidine, the core unit for these alkaloids, has occupied an important position as bioactive targets and useful synthetic intermediates. Consequently, several synthetic approaches have been developed for the synthesis of these alkaloids ${ }^{[2]}$.

(-)-Allosedridine 1 and $(+)$-allosedridine $2^{[3]}$ were both isolated from Sedum nudum ${ }^{[4]}$, which were observed to exhibit memory-enhancing properties upon their isolation and may be effective for the treatment of Alzheimer's disease ${ }^{[5]}$. For the novel biological activity, we became interested in the synthesis of such natural products. Herein, we explored our synthetic study towards (-)-allosedridine 1.<smiles>C[C@H](O)C[C@@H]1CCCCN1</smiles>

(-)-Allosedridine

1<smiles>CCCC1NCCCC1OC</smiles><smiles>O[C@H](CC1CCCCC1)c1ccccc1</smiles>

(-)-Sedamine 7
5

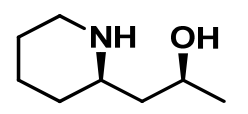

(+)-Allosedridine

2

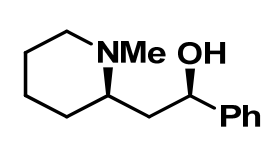

(+)-Sedamine

8<smiles>C[C](O)CC1CCCCN1</smiles>

(-)-Sedridine

3<smiles>CCC[C@H](O)CC1CCCCN1</smiles>

(-)-Halosaline

6<smiles>CN1CCCCC1CC(O)c1ccccc1</smiles>

(+)-Allosedamine

9

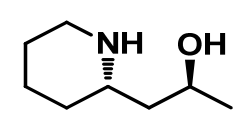

(+)-Sedridine

4

Figure 1. 2-Substituted piperidine alkaloids

Our retrosynthetic analysis of (-)-allosedridine $\mathbf{1}$ is outlined in Scheme 1, which actually represented a general stereoselective synthetic method for preparing $\mathbf{1}$ and $\mathbf{2}$. 


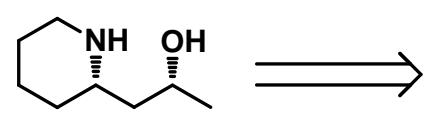

1<smiles>CC(CC1CCCC(=O)N1)O[Na]</smiles>

11

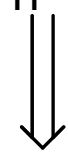<smiles>CO[R16](=O)OC(C)C[C@@H](N)C/C=C/C(=O)OC</smiles>

12
13

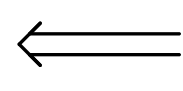

(1)<smiles>COc1ccc(CO)cc1</smiles><smiles>CCOC(C)CC(=O)OC</smiles>

14<smiles>COC(=O)CC(C)O</smiles>

15

Scheme 1. Retrosynthetic route of (-)-Allosedridine

In our retrosynthetic analysis, we envisioned that the target molecule $\mathbf{1}$ could be achieved from (S)-6-((R)-2-((4-methoxybenzyl)oxy)propyl)piperidin-2-one 11 via a deprotection of PMB group and few transformation steps. Compound 11 was designed to be obtained from azide 12, which in turn obtained from aldehyde 13 via a few steps. For the compound 13, it could be easily obtained from ester 14 via a reduction, such using $\mathrm{LiAlH}_{4}$ and following a Swern oxidation. The compound 14 could be got from the commercial available material (R)-methyl 3-hydroxybutanoate 15 via a protection. In this paper, we just reported the synthesis of compound 13. The detailed route of 13 was show in scheme 2 . The synthetic study towards the total synthesis of (-)-allosedridine $\mathbf{1}$ is going on based on 13.

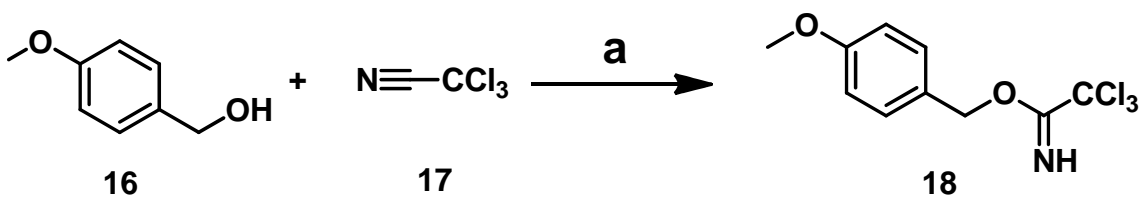

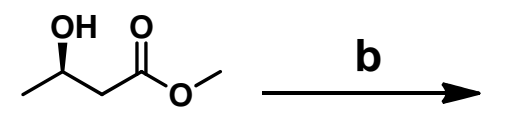

15

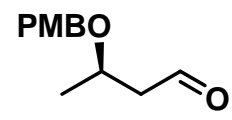

13<smiles>COC(=O)C[C@@H](C)OS(C)(=O)=O</smiles>

14

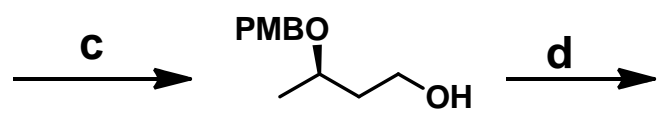

19

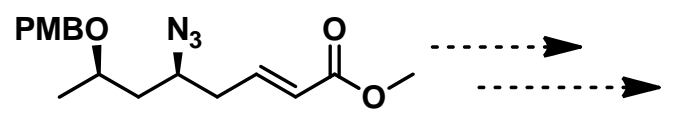

12<smiles>C[C@@H](O)C[C@@H]1CCCCN1</smiles>

1

a) $\mathrm{NaH}(60 \%), \mathrm{Et}_{2} \mathrm{O}, 0^{\circ} \mathrm{C}$ to r.t., 2h; b) 18, CSA, DCM, r.t.,18h; c) $\mathrm{LiAlH}_{4}, \mathrm{Et}_{2} \mathrm{O}, 0^{\circ} \mathrm{C}, 30$ min; d) $(\mathrm{COCl})_{2}, \mathrm{DMSO}, \mathrm{Et}_{3} \mathrm{~N}, \mathrm{DCM},-78^{\circ} \mathrm{C}, 3 \mathrm{~h}$

Scheme 2. Synthetic route of compound $\mathbf{1 3}$

\section{Experimental}

NMR spectra were recorded on Bruker AV-400MHz spectrometers. The solvents and reagents were purified and dried according to standard procedures: $\mathrm{CH}_{2} \mathrm{Cl}_{2}$, THF, DMF were distilled from $\mathrm{CaH}_{2}$ prior to use. 


\section{4-methoxybenzyl 2, 2, 2-trichloroacetimidate 18}

At $0^{\circ} \mathrm{C}$, sodium hydride $(60 \%, 40.2 \mathrm{mg}, 1.01 \mathrm{mmol})$ was added to (4-methoxyphenyl)methanol 16 (556 mg, $4.02 \mathrm{mmol}$ ) under nitrogen, which was previously solubilized in anhydrous ether (1.5 $\mathrm{mL}$ ). The mixture was stirred for $30 \mathrm{~min}$ at room temperature and then cooled at $0{ }^{\circ} \mathrm{C}$. Trichloroacetonitrile 17 (403 mL, $4.024 \mathrm{mmol})$ was then added. The mixture was allowed to be stirred for $2 \mathrm{~h}$ at room temperature, then it was neutralized with saturated $\mathrm{NaHCO}_{3}$ solution and washed with hexane $(5 \mathrm{~mL})$. Organic layer was extracted and then dried over $\mathrm{MgSO}_{4}$ and subsequently concentrated to give the crude compound $18(1.090 \mathrm{~g}, 3.858 \mathrm{mmol}, 96 \%)$ as oil. $\mathrm{R}_{\mathrm{f}}$ (petroleum ether/AcOEt: $1: 1)=0.78 ;{ }^{1} \mathrm{H} \mathrm{NMR}\left(400 \mathrm{MHz}, \mathrm{CDCl}_{3}\right): \delta 3.71\left(\mathrm{~s}, 3 \mathrm{H},-\mathrm{CH}_{3} \mathrm{O}\right), 5.18(\mathrm{~s}$, $\left.2 \mathrm{H},-\mathrm{CH}_{2} \mathrm{O}\right), 6.81(\mathrm{~d}, 2 \mathrm{H},-2 \mathrm{CH}$ aromatics, $8.7 \mathrm{~Hz}), 7.27(\mathrm{~d}, 2 \mathrm{H},-2 \mathrm{CH}$ aromatic).

\section{(R)-methyl 3-((4-methoxybenzyl)oxy)butanoate 14}

Under a nitrogen atmosphere, p-Methoxybenzyl trichloroacetimidate 18 (987 mL, $4.754 \mathrm{mmol})$ was added to (R)-methyl 3-hydroxybutanoate15 (351 $\mathrm{mg}, 2.971 \mathrm{mmol}$ ) dissolved in dichloromethane $(30 \mathrm{~mL})$ dropwise and camphorsulfonic acid $(69 \mathrm{mg}, 0.297 \mathrm{mmol})$ was added. After $18 \mathrm{~h}$, the mixture was treated with saturated $\mathrm{NaHCO}_{3}$. After extraction with $\mathrm{DCM}(3 \times 30 \mathrm{~mL})$, organic phases were dried over $\mathrm{MgSO}_{4}$, filtered and then concentrated. Crude product was purified on silica gel (petroleum ether/AcOEt: 1:20) to furnish the pure compound 14 (680 $\mathrm{mg}, 2.852 \mathrm{mmol}$, 96\%) as yellow oil. ${ }^{1} \mathrm{H}$ NMR $\left(400 \mathrm{MHz}, \mathrm{CDCl}_{3}\right): \delta 1.26(\mathrm{~d}, 3 \mathrm{H}), 2.42-2.68(\mathrm{~m}, 2 \mathrm{H}), 3.69(\mathrm{~s}, 3 \mathrm{H})$, $3.81(\mathrm{~s}, 3 \mathrm{H}), 4.00(\mathrm{~m}, 1 \mathrm{H}), 4.485(\mathrm{~m}, 2 \mathrm{H}), 6.89(\mathrm{~d}, 2 \mathrm{H}), 7.27(\mathrm{~d}, 2 \mathrm{H}) .{ }^{13} \mathrm{C}$ NMR $(400 \mathrm{MHz}, \mathrm{CDCl} 3)$ $\delta: 171.46,158.67,130.11,128.75,113.44,113.27,71.07,70.02,54.77,51.06,41.36,19.37$.

\section{(R)-3-((4-methoxybenzyl)oxy)butan-1-ol 19}

To an ice-cold suspension of $\mathrm{LiAlH}_{4}(2.32 \mathrm{~g}, 61.1 \mathrm{mmol})$ in ether $(90 \mathrm{~mL})$ was added a solution of $14(14.56 \mathrm{~g}, 61.1 \mathrm{mmol})$ dissolved in ether $(30 \mathrm{~mL})$, and the mixture was stirred at $0^{\circ} \mathrm{C}$ for 30 min and warmed to room temperature. Then the mixture was cooled to $0^{\circ} \mathrm{C}$ again, EtOAc $(27 \mathrm{~mL}$, $0.31 \mathrm{~mol}), \mathrm{H}_{2} \mathrm{O}(22 \mathrm{~mL}, 1.22 \mathrm{~mol})$ were added to the mixture. The resulting mixture was stirred vigorously at room temperature for $1 \mathrm{~h}$ and filtered through a pad of Celite with EtOAc. The filtrate was concentrated, and the residue was purified by chromatography (hexane/EtOAc) to afford alcohol 19 (9.61 g, 95\%). ${ }^{1} \mathrm{H}$ NMR $\left(400 \mathrm{MHz}, \mathrm{CDCl}_{3}\right) \delta: 7.27(\mathrm{~d}, J=4.2 \mathrm{~Hz}, 2 \mathrm{H}), 6.89(\mathrm{~d}, J=4.2 \mathrm{~Hz}$, $2 \mathrm{H}), 4.58(\mathrm{~d}, J=5.6 \mathrm{~Hz}, 1 \mathrm{H}), 4.38(\mathrm{~d}, J=5.6 \mathrm{~Hz}, 1 \mathrm{H}), 3.81(\mathrm{~s}, 3 \mathrm{H}), 3.79-3.73(\mathrm{~m}, 3 \mathrm{H}), 2.71(\mathrm{~s}, 1 \mathrm{H})$, $1.79-1.74(\mathrm{~m}, 2 \mathrm{H}), 1.25(\mathrm{~d}, J=3 \mathrm{~Hz}, 3 \mathrm{H}) ;{ }^{13} \mathrm{C} \mathrm{NMR}\left(400 \mathrm{MHz}, \mathrm{CDCl}_{3}\right) \delta: 159.21,130.46,129.37$, $113.88,74.43,70.09,61.02,55.29,38.75,19.39$.

\section{(R)-3-((4-methoxybenzyl)oxy)butanal 13}

Under a nitrogen atmosphere, to a solution of $(\mathrm{COCl})_{2}(3.8 \mathrm{~mL}, 43.6 \mathrm{mmol})$ in $\mathrm{CH}_{2} \mathrm{Cl}_{2}(90 \mathrm{~mL})$ was injected DMSO $(6.14 \mathrm{~mL}, 86.5 \mathrm{mmol})$ at $-78{ }^{\circ} \mathrm{C}$. The solution was stirred at the same temperature for $15 \mathrm{~min}$, and a solution of alcohol $19(6.1 \mathrm{~g}, 29.0 \mathrm{mmol})$ dissolved in $\mathrm{CH}_{2} \mathrm{Cl}_{2}$ (30 $\mathrm{mL})$ was added. After $1 \mathrm{~h}$ of stirring at $-78{ }^{\circ} \mathrm{C}, \mathrm{Et}_{3} \mathrm{~N}(28.3 \mathrm{~mL}, 204 \mathrm{mmol})$ was added, and the resulting mixture was warmed gradually to $0{ }^{\circ} \mathrm{C}$ over $2 \mathrm{~h}$. Brine was added to the mixture, and the product was extracted with $\mathrm{Et}_{2} \mathrm{O}$ three times. The combined ethereal solutions were washed with brine, dried, and concentrated to give aldehyde 13 as a yellow oil $(5.34 \mathrm{~g}, 90 \%) .{ }^{1} \mathrm{H}$ NMR (400 $\left.\mathrm{MHz} \mathrm{CDCl}_{3}\right) \delta: 9.67(\mathrm{~s}, 1 \mathrm{H}), 7.15(\mathrm{~d}, J=4.2 \mathrm{~Hz}, 2 \mathrm{H}), 6.78(\mathrm{~d}, J=4.2 \mathrm{~Hz}, 2 \mathrm{H}), 4.44(\mathrm{~d}, J=5.6 \mathrm{~Hz}$, $1 \mathrm{H}), 4.31(\mathrm{~d}, J=5.6 \mathrm{~Hz}, 1 \mathrm{H}), 3.98-3.95(\mathrm{~m}, 1 \mathrm{H}), 3.70(\mathrm{~s}, 3 \mathrm{H}), 2.62-2.55(\mathrm{~m}, 1 \mathrm{H}), 2.43-2.38(\mathrm{~m}, 1 \mathrm{H})$, $1.19(\mathrm{~d}, J=3 \mathrm{~Hz}, 3 \mathrm{H}) ;{ }^{13} \mathrm{C}$ NMR $\left(400 \mathrm{MHz}, \mathrm{CDCl}_{3}\right) \delta: 201.06,158.75,129.81,128.81,113.34$, $69.78,69.38,54.78,50.01$.

\section{Acknowledgement}

We thank the Science and Technology Project of Jiangxi Province Education Department (GJJ14579), Science and Technology Planning Project of Jiangxi Province (20142BBE50006), Scientific Research Fund of Jiangxi Provincial Education Department (No.KJLD12036). 


\section{References}

[1] (a) Strunzand, G. M.; Finlay, J. A. In The Alkaloids; Brossi, A., Ed.; Academic Press: San Diego, 1986; Vol. 26, p 89; (b) Michael, J. P. Nat. Prod. Rep. 2008, 25, 139-165; (c) Daly, J. W.; Garraffo, H. M.; Spande, T. In Alkaloids: Chemical and Biological Perspectives; Pelletier, S. W., Ed.; Academic Press: San Diego, 1999; Vol. 13, pp 1-161.

[2] (a) Rice, G. T.; White, M. C. J. Am. Chem. Soc. 2009, 131, 11707-11711; (b) Williams, D. R.; Osterhout, M. H.; Amato, G. S. Heterocycles. 2004, 64, 45-50; (c) Bates, R. W.; Sa-Ei, K. Tetrahedron. 2002, 58, 5957-5978.

[3] (a) Davis, F. A.; Prasad, K. R.; Nolt, M. B.; Wu, Y. Org. Lett. 2003, 5, 925; (b) Takahata, H.; Kubota, M.; Ikota, N. J. Org. Chem. 1999, 64, 8594; (c) Louis, C.; Hottele, C. Tetrahedron: Asymmetry 1997, 8, 109; (d) Littler, B. J.; Gallagher, T.; Boddy, I. K.; Riordan, P. D. Synlett 1997, 22.

[4] Buffat, M. G. P. Tetrahedron. 2004, 60, 1701.

[5] (a) Micel, K.-H.; Sandberg, F.; Haglid, F.; Norin, T. Acta Pharm. Suec. 1967, 4, 97; (b) Micel, K.-H.; Sandberg, F.; Haglid, F.; Norin, T.; Chan, R. P. K.; Craig, J. C. Acta Chem. Scand. 1969, 23, 3479 . 